\title{
BIOMETRIC CHARACTERISTICS OF 'CATHERINE SEL 1' PEACH CULTIVAR IN SEMIARID ENVIRONMENT
}

\author{
Leinar Septar ${ }^{1, *}$, Cristina Moale ${ }^{1}$, Ion Caplan ${ }^{1}$, Luana Bocioroaga ${ }^{1}$ \\ ${ }^{1}$ Research Station for Fruit Growing (RSFG) Constanta, 25 Pepinierei Street, \\ Valu lui Traian, Constanta, Romania
}

\begin{abstract}
In arid and semi-arid regions, irrigation application is mandatory for modern fruit growing, but the optimal irrigation application requires large amounts of water. In the context of global warming, water saving is a major objective. Therefore, deficit irrigation (DI) is an attractive alternative. The plant studied was thirteen years old 'Catherine Sel.1' peach trees. The trees were grafted on franc rootstock and planted in a $4 \mathrm{~m} \times 3 \mathrm{~m}$ layout. Soil management was represented by clean cultivation both between tree rows and in the row. Fruit size and weight are important qualities and yield traits in peach (Prunus persica $(L)$ Batsch), but the factors that influence fruit size and weight remain to be explored. The fruit biometrical characteristics was influenced by the irrigation regime, with the irrigated treatment with $100 \%$ AHI (T1) showing significantly ( $P<5 \%$ ) higher differences versus T2 and T3. As with fruit biometrical characteristics, the fruit weight determined on the fruits of the studied treatments had the same trend. In this study, we investigated the impact of stress hydric on fruit size and weight at 'Catherine sel 1' peach cultivar in 2019-2020 period.
\end{abstract}

Keywords: climatic conditions, longitudinal diameter of fruit, Prunus persica.

\section{INTRODUCTION}

Deficit irrigation (DI) has been proposed as a technique that irrigates the entire root zone with less than evapotranspiration needs and leads to reduced irrigation water use while maintaining farmers net profits (Hoffman et al., 1990). A decline in water availability for irrigation and the positive results obtained with DI in some fruit tree crops have renewed the interest in developing information on deficit irrigation for a variety of crops (FAO Report, 2002; Fereres and Soriano, 2007).

The concept of regulated deficit irrigation (RDI) was first proposed by Chalmers et al. (1981) and Mitchell and Chalmers (1982) to control vegetative growth in peach orchards, and they found that savings in irrigation water could be realized without reducing yield. Nevertheless, experiments with RDI have been successful in many fruit tree and nut species such as apricot (Ruiz-Sánchez et al., 2000), almond (Goldhamer et al., 2000), pistachio (Goldhamer and Beede, 2004). In Romania, peach is highly appreciated, but its favorability area is relatively restricted from the climate view point. It finds proper climate conditions in Dobrogea region, Romania, (winter temperatures not too low), more favorable than in other regions of the country. 
The purpose of this study is to establish the impact of stress hydric on biometric characteristics and weight of the peach fruits.

\section{MATERIALS AND METHODS}

Climate and soil conditions. The studied orchard is located in village Agigea $\left(44^{\circ} 05^{\prime}\right.$ Northern latitude and $28^{\circ} 37^{\prime}$ 'Eastern longitude), Dobrogea region, Romania. This is a semi-arid region with a climatic water deficit (WD, as difference between the annual values of precipitation (P) and Penman-Monteith reference evapotranspiration (PM-ETo) of about $-405 \mathrm{~mm}$ on the Black Sea costal area (Paltineanu et al., 2007). The climate conditions at the experimental site are specific for a semiarid region, with a mean annual air temperature of $12.0^{\circ} \mathrm{C}$, a mean annual precipitation amount of $425.8 \mathrm{~mm}$ and reference evapotranspiration totalizes $827.5 \mathrm{~mm}$ annually for $1980 \div 2009$ period (Paltineanu et al., 2016a). Climatic data were recorded by automatic weather stations (WatchDog Weather Station 2000, Spectrum Technologies Inc., Aurora Illinois, USA and iMetos, IMT300, Pessl Instruments, Austria) by a 1-h step. These data were periodically transferred to a laptop and processed as diurnal means and used in calculations. The soil is a calcaro-calcic chernozem (*World Reference Base for Soil Resources, 2006) with a loamy texture and alkaline $\mathrm{pH}$, a proper soil structure and high fertility in topsoil $(0-60 \mathrm{~cm})$. Land slop is between 1.0 and $3.0 \%$ and soil bulk density around $1.20 \mathrm{~g} \mathrm{~cm}^{-3}$. The normal tree rooting depth was $80 \mathrm{~cm}$ (Indreias, 1997), with field capacity and wilting point values of the soil at 0.300 and $0.125 \mathrm{~cm}^{3} \mathrm{~cm}^{-3}$, respectively.

Experimental design and irrigation application. The split-plot experiment described here is mono-factorial with irrigation strategy having three graduations. The peach tree (Prunus persica $(L)$ Batsch) was selected for this study because is representative for this region. The biological material is representing by 'Catherine sel 1' cultivar omologated in 2004 . The study was carried out during two years $(2019 \div 2020)$. The fruit trees were planted in spring 2006 , in a $4 \mathrm{~m} \times 3 \mathrm{~m}$ layout. The studied plots comprised three adjacent fruit tree rows with the central row containing three trees for measurements and observations. The canopy shape was a classic vase and the soil management systems was clean cultivation both between tree rows and in the row. The irrigation regime consisted of the following treatments: T1- irrigated at 100\% AHI (active humidity interval), T2irrigated at $70 \%$ AHI and T3-control, non-irrigated treatment. The watering method used was drip irrigation. The dripper spacing was $0.6 \mathrm{~m}$ and the dripper discharge about $2.0 \mathrm{Lh}^{-1}$. The irrigation aplicated in June and August in 2019 and from April to August in 2020. We applied only four irrigations in 2019 with $20 \mathrm{~mm}$ in T1 and $10 \mathrm{~mm}$ in T2, totaling $80 \mathrm{~mm}$ in T1 and $40 \mathrm{~mm}$ in T2, respectively. However, there were six irrigation applications during the dryer period in 2020, each of $20 \mathrm{~mm}$ in T1 and $10 \mathrm{~mm}$ in T2, totaling $120 \mathrm{~mm}$ and $60 \mathrm{~mm}$, respectively. No water was applied in $\mathrm{T} 3$.

Soil water content measurements. Soil water matric potential (SWP) was measured with Watermark resistance blocks (6450 Watermark Soil Moisture Sensor, Spectrum Technologies, Inc) installed for each fruit tree at four depths: 20, 40, 60 and $80 \mathrm{~cm}$ at a $150 \mathrm{~cm}$ distance from the tree trunk. The sensors were placed on the same vertical line at $45^{\circ}$ angles below horizontal according to the method described by Paltineanu and Howse (1999). These data were recorded by WatchDog dataloggers (WatchDog Model 1650 Data Logger, Spectrum Technologies, Inc) and downloaded periodically by a laptop. The relationships between SWP measured with the Watermark sensors and 
soil water content (SWC) measured gravimetrically were previously determined from field data (Paltineanu et al., 2011b); these relationships were then used to transform soil water matric potential readings into $\mathrm{SWC}$ values during the experiment.

Fruit determinations. Each year was tested average samples of 15 fruits/treatment. Fruit growth was monitored by measuring longitudinal and transversal fruit diameter and fruit height after harvest. The measurements were performed using an metric digital caliper (Insize Co., Ltd. China). The average weight of a fruit was determined by weighing 10 fruits/treatment and dividing by the number of weighed fruits. The weighing of the fruit was performed with a precision balance (Kern \& Sohn GmbH, Germany). Fruit were harvested between the $23^{\text {rd }}$ to the $24^{\text {th }}$ of July in 2019 and from $27^{\text {th }}$ to the $28^{\text {th }}$ of July in 2020 .

\section{Data analyses}

SPSS 14.0 software and Microsoft Office Excel were used for the analysis of variance and various calculations for fruit quality properties. Different letters in the graphs indicate significant differences for the probability $(\mathrm{P}) \leq 0.05$ according to Duncan`s multiple range test.

\section{RESULTS AND DISCUSSIONS}

\section{Climate conditions}

During the growing season in the experimental period the mean yearly maximum and minimum air temperatures were 26.9 and $12.9^{\circ} \mathrm{C}$, respectively, versus the long-term yearly means of 22.5 and $14.8^{\circ} \mathrm{C}$. The mean annual air temperature was $19.9^{\circ} \mathrm{C}$, versus $18.5^{\circ} \mathrm{C}$ for long-term, showing a trend of warming in the area. In the growing season, the mean annual precipitation amount was 159.2 $\mathrm{mm}$, versus $224.2 \mathrm{~mm}$ for long-term, almost similar, and mean annual reference evapotranspiration was $735.9 \mathrm{~mm}$, versus $661.5 \mathrm{~mm}$ for long-term, showing also a trend of dryness. ETo values were on average 145.0, 147.0 and $136.4 \mathrm{~mm} \mathrm{month}^{-1}$ during June, July and August, respectively. The average value of climatic water deficit (WD) in the growing season of the study period was -576.0 $\mathrm{mm}$, versus -437.3 for long-term. The mean value of yearly and monthly climate data during the growing season in the experimental period is shown in the table $1(a, b)$. The period of experiment $(2017 \div 2020)$ was considered as a relatively normal period, showing however an aridization trend, with monthly temperature means of $22.7^{\circ} \mathrm{C}$ in June, $23.8^{\circ} \mathrm{C}$ in July and $24.6^{\circ} \mathrm{C}$ in August, respectively.

Table 1a. The mean value of annual climate data during the growing season in the $2017 \div 2020$ experimental period versus the long-term, $1980 \div 2009$, Agigea, Romania

\begin{tabular}{lcc}
\hline \multicolumn{1}{c}{ Climatic data } & \multicolumn{2}{c}{ Growing season } \\
\cline { 2 - 3 } & $\mathbf{2 0 1 7} \div \mathbf{2 0 2 0}$ & $\mathbf{1 9 8 0} \div \mathbf{2 0 0 9}$ \\
\hline Mean air temperature, $\mathrm{T}_{\text {med }}\left({ }^{\circ} \mathrm{C}\right)$ & 19.9 & 18.5 \\
Mean maximum air temperature, $\mathrm{T}_{\max }\left({ }^{\circ} \mathrm{C}\right)$ & 26.9 & 22.5 \\
Mean minimum air temperature, $\mathrm{T}_{\min }\left({ }^{\circ} \mathrm{C}\right)$ & 12.9 & 14.8 \\
Precipitation, $\mathrm{P}(\mathrm{mm})$ & 159.2 & 224.2 \\
Reference evapotranspiration, $\mathrm{PM}-\mathrm{ET}_{0}(\mathrm{~mm})$ & 735.9 & 661.5 \\
Water Deficit/Water Excess, WD/WE $(\mathrm{mm})$ & -576.0 & -437.3 \\
\hline
\end{tabular}


Current Trends in Natural Sciences

Vol. 10, Issue 19, pp. 381-386, 2021

https://doi.org/10.47068/ctns.2021.v10i19.050

Current Trends in Natural Sciences (on-line)

Table $1 b$. The mean value of monthly climate data during the growing season in the experimental period $2017 \div 2020$, Agigea, Romania

\begin{tabular}{lcccccc}
\hline \multicolumn{1}{c}{ Climatic data } & \multicolumn{7}{c}{ Growing season } \\
\cline { 2 - 6 } & Apr & May & Jun & Jul & Aug & Sep \\
\hline $\begin{array}{l}\text { Mean air temperature, } \\
\mathrm{T}_{\text {med }}\left({ }^{\circ} \mathrm{C}\right)\end{array}$ & 11.0 & 17.0 & 22.7 & 23.8 & 24.6 & 20.4 \\
$\begin{array}{l}\text { Mean maximum } \\
\text { air temperature, } \mathrm{T}_{\max }\left({ }^{\circ} \mathrm{C}\right)\end{array}$ & 18.1 & 23.6 & 29.7 & 30.9 & 32.0 & 27.3 \\
$\begin{array}{l}\text { Mean minimum air } \\
\text { temperature, } \mathrm{T}_{\min }\left({ }^{\circ} \mathrm{C}\right)\end{array}$ & 3.9 & 10.5 & 15.8 & 16.7 & 17.0 & 13.5 \\
$\begin{array}{l}\text { Precipitation, } \mathrm{P}(\mathrm{mm}) \\
\text { Reference evapotranspi- }\end{array}$ & 17.1 & 18.7 & 39.8 & 58.6 & 4.8 & 20.2 \\
ration, PM-ET $(\mathrm{mm})$ & 95.2 & 129.0 & 145.0 & 147.0 & 136.4 & 83.3 \\
Water Deficit/Water Excess, & -78.2 & -110.0 & -105.0 & -88.2 & -132 & -63.0 \\
WD/WE $(\mathrm{mm})$ & & & & & & \\
\hline
\end{tabular}

\section{Soil water content (SWC) during in irrigation period}

In 2019, the dynamics of soil water content (SWC) as a result of the four irrigation applications is shown in Figure 2a. It is noted that both in T1 and T2, the SWC values ranged from FC to MAD (management allowed deficit, mid-interval between FC and WP), except for the values from T2 treatment, last watering, which are found in the interval MAD and WP, with values close to MAD. The SWC values in T3 were between MAD and WP, due to the dry year.

In 2020, following the application of the six waterings the dynamics of soil water content is illustrated in Figure 2b. Thus, in the irrigated treatments, the SWC values oscillated in the range between FC and MAD. In T3, SWC values were to half interval between MAD and WP, with values approaching to WP at the end of vegetation period.

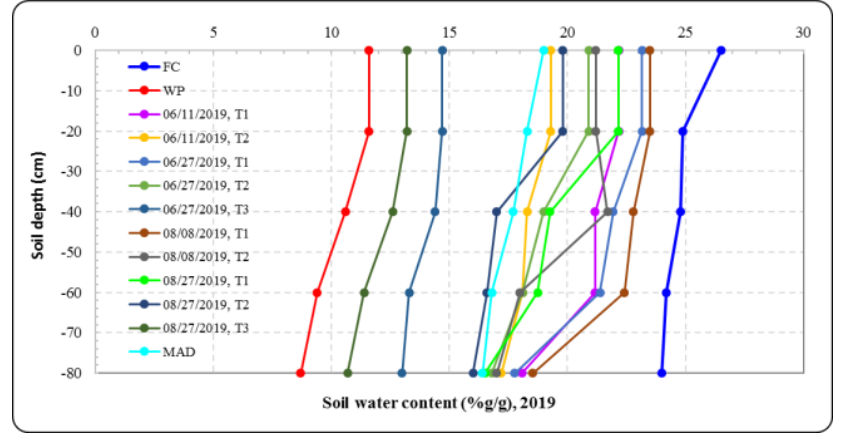

Figure 2a. Soil water content (SWC) profiles in the treatments studied Agigea village, Dobrogea, Romania-2019

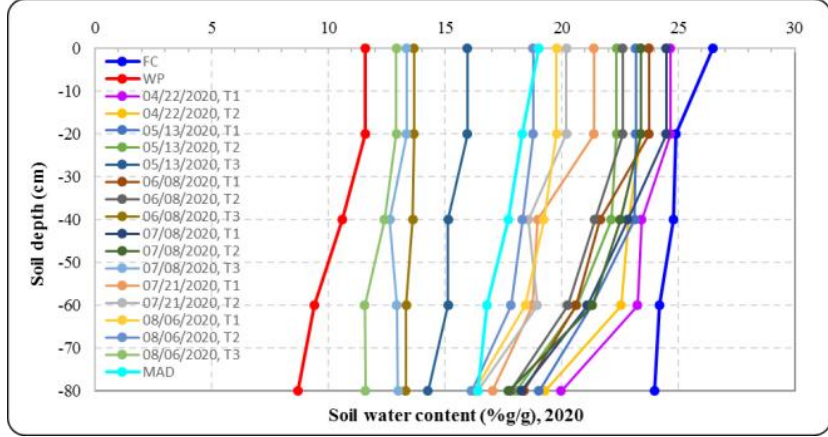

Figure 2b. Soil water content (SWC) profiles in the treatments studied Agigea village, Dobrogea, Romania-2020

\section{Biometrical measurements and weight to peach fruits}

After harvesting, the fruits of experience has been subjected to biometrical measurements and fruits weithing. The values presented represent average values of the two years of study. Thus, peach fruits had a longitudinal diameter of $52.0 \mathrm{~mm}$ to $81.0 \mathrm{~mm}$. Fruits in the T1 treatment were much big, followed by the fruits from the $\mathrm{T} 2$ treatment. The smallest longitudinal diameter was found in T3 treatment. Figure 3 shows that there were significant differences between the treatments studied 
Current Trends in Natural Sciences

Vol. 10, Issue 19, pp. 381-386, 2021

https://doi.org/10.47068/ctns.2021.v10i19.050

Current Trends in Natural Sciences (on-line)

on fruit's longitudinal diameter, as indicated by different letters accoring to the probability $(\mathrm{P}) \leq$ 0.05 according to Duncan`s multiple range test. As with fruit longitudinal diameter, the transversal diameter determined on the fruits of the studied treatments had the same trend. The highest value was obtained in $\mathrm{T} 1$ treatment, $70.3 \mathrm{~mm}$ and the lowest value in T3 treatment, $51.9 \mathrm{~mm}$, respectively. Figure 4 shows significant differences, written with different letters, between the treatments studied regarding the fruits transversal diameter. The height of the fruits determined of the studied treatments had the same trend. The peach fruits had a height of $51.0 \mathrm{~mm}$ to $71.0 \mathrm{~mm}$. Figure 5 shows significant differences between the treatments studied regarding the fruits height. As with fruit biometrical characteristics, the fruit weight determined on the fruits of the studied treatments had the same trend. The highest value was obtained in T1 treatment, $163.5 \mathrm{~g}$ and the lowest value in T3 treatment, $83.7 \mathrm{~g}$, respectively. Figure 6 shows significant differences between the treatments studied regarding the fruits weight.

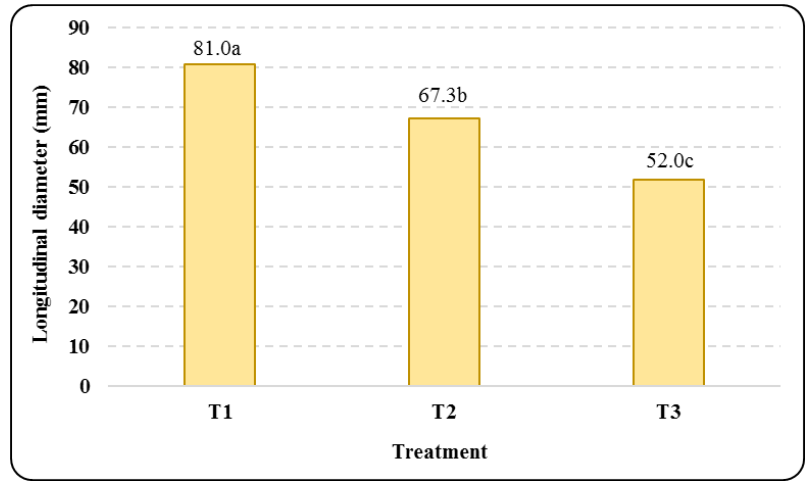

Figure 3. Longitudinal diameter $(\mathrm{mm})$ of the peach fruits, 2019-2020

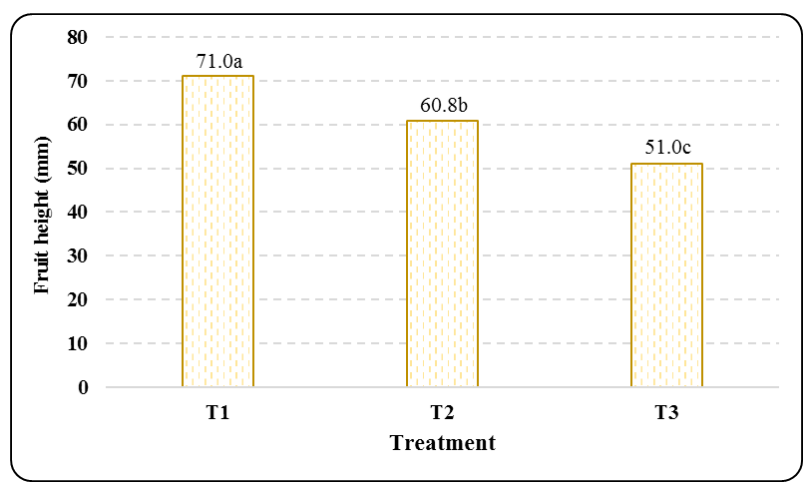

Figure 5. Fruit height ( $\mathrm{mm}$ ) of the peach fruits, 2019-2020

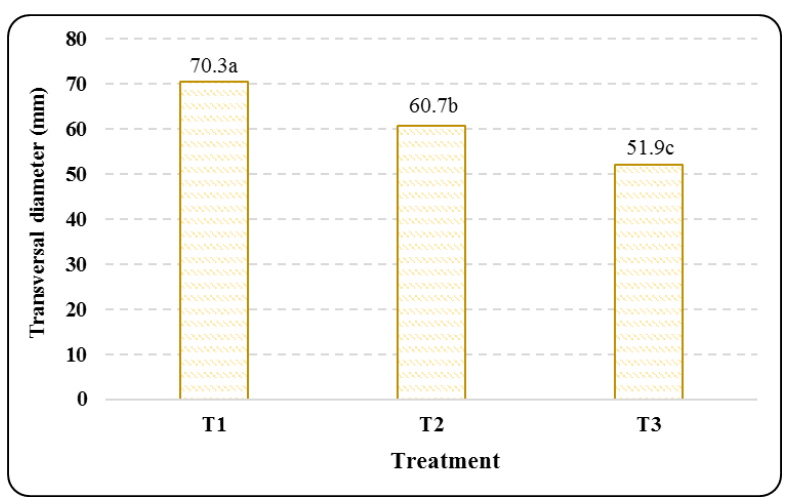

Figure 4. Transversal diameter $(\mathrm{mm})$ of the peach fruits, 2019-2020

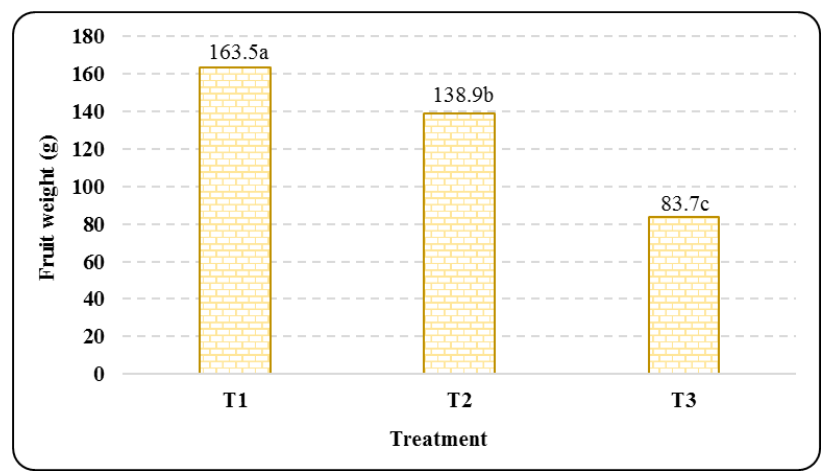

Figure 6. Fruit weight (g) of the peach fruits, 2019-2020

\section{CONCLUSIONS}

In the context of global warming, water saving is a major objective. Therefore, irrigation with hydric stress is an attractive alternative.

In the irrigated treatments, T1 and T2, the SWC values oscillated in the range between FC and MAD. 
The fruit biometrical characteristics was influenced by the irrigation regime, with the irrigated treatment with $100 \%$ AHI (T1) showing significantly ( $\mathrm{P}<5 \%)$ higher differences versus $\mathrm{T} 2$ and $\mathrm{T} 3$. As with fruit biometrical characteristics, the fruit weight determined on the fruits of the studied treatments had the same trend.

The study suggests that a moderate water stress can be profitable for enhancing key fruit biometrical characteristics.

\section{ACKNOWLEDGEMENTS}

This work was supported by a grant of the Romanian Ministery of Research and Innovation, CCCDIUEFISCDI, project number PN-III-P1-1.2-PCCDI-2017-0332/Project 2 "Multisensory quantification of water and biocenotic stress in horticulture through phytomonitoring and early warning in climate change conditions", within PNCDI III.

\section{REFERENCES}

Chalmers, D.J., Mitchell, P.D. \& van Heek, L. (1981). Control of peach tree growth and productivity by regulated water supply, tree density and summer pruning. Journal of the American Society of Horticultural Science, 106, 307-12.

FAO. (2002). Deficit Irrigation Practices Report, FAO, Rome, p. 102.

Fereres, E., Soriano, M. A. (2007). Deficit irrigation for reducing agricultural water use. Journal of Experimental Botany, 58 (2), 147-159.

Goldhamer, D.A., Salinas, M. (2000). Evaluation of regulated deficit irrigation on mature orange trees grown under high evaporative demand. In: Proceedings of the International Society of Citriculture, IX Congress, Orlando, 227-231.

Goldhamer, D.A., Beede, R.H. (2004). Regulated deficit irrigation effects on yield, nut quality and water-use efficiency of mature pistachio trees. Journal of Horticultural Science and Biotechnology, 79, 538-545.

Hoffman, G. J., Towell, T. A. and Solomon, K. H. (1990). Management of farm irrigation systems, ASAE, St. Joseph, MI, USA.

Indreias, A. (1997). Arhitectonica sistemului radicular la soiul Springrest altoit pe sase portaltoi. In: Ionescu, V. (Ed). Lucrari stiintifice. INFCON Constanta, 203-210.

Mitchell, P.D. and D.J. Chalmers. (1982). The effect of reduced water supply on peach tree growth and yield. J. Amer. Soc. Hort. Sci., 107, 853-856.

Paltineanu, C., and Howse, R.K. (1999). Installing suction samplers to collect nitrate-leaching and monitoring soil moisture and hydraulic potential during an infiltration experiment within swell-shrink soils. Stiinta sol, no. 2, vol XXXIII, 9-22.

Paltineanu C., Mihailescu, I.F., Seceleanu, I., Dragota, C., and Vasenciuc F. (2007). Using aridity indexes to describe some climate and soil features in Eastern Europe: a Romanian case study. Theoretical and applied climatology, Springer Velag Vienna, Volume 90, no. 3-4, 263-274.

Paltineanu, C., Septar, L., Moale, C., Oprita, A., and Lamureanu, G. (2011b). Peach Irrigation under soil water stress in the south-eastern part of Romania. Acta Horticulturae, 922, 195-202.

Paltineanu, C., Septar, L., and Chitu, E. (2016a). Temperature profile in apricot tree canopies under the soil and climate conditions of the Romanian Black Sea Coast. Int. J. Biometeorol., 60, 401-410.

Ruiz-Sánchez, M.C., Torrecillas, A., Pérez-Pastor, A., Domingo, R. (2000). Regulated deficit irrigation in apricot trees. Acta Horticulturae, 537, 759-766.

World Reference Base for Soil Resources (2006). A framework for international classification, correlation and communication. Food and Agriculture Organization of the United Nations, Rome, p. 145 http://epic.awi.de/35324/1/wsrr103e.pdf. 